\title{
PENGARUH PEMBERIAN PUPUK GUANO DAN PUPUK GROWMORE TERHADAP PERTUMBUHAN BIBIT KOPI ROBUSTA (Coffea robusta L.)
}

\author{
Karnilawati(1), Rudi Fadhli(2), Muksalmina (3) \\ 1,2Jurusan Agroteknologi Fakultas Pertanian Universitas Jabal Ghafur, Sigli \\ 3Mahasiswa Agroteknologi Fakultas Pertanian Universitas Jabal Ghafur, Sigli
}

\begin{abstract}
ABSTRAK
Usaha kopi organik dapat dijadikan sebagai salah satu alternatif dalam meningkatkan mutu kopi robusta di Indonesia. Penelitian ini bertujuan untuk mengetahui pemberian pupuk guano dan growmore terhadap pertumbuhan bibit kopi robusta. Penelitian dilaksanakan di Kebun Percobaan Fakultas Pertanian Universitas Jabal Ghafur Glee Gapui Sigli mulai Februari sampai April 2017. Penelitian ini menggunakan Rancangan Acak Kelompok (RAK) pola faktorial 4x3 dengan 3 ulangan. Faktor pertama pupuk guano terdiri dari 4 taraf yaitu 1 bagian pupuk guano dengan 2 bagian tanah (1:2), 1 bagian pupuk guano dengan 3 bagian tanah (1:3), 1 bagian pupuk guano dengan 4 bagian tanah (1:4) dan 1 bagian pupuk guano dengan 5 bagian tanah (1:5). Faktor kedua konsentrasi growmore terdiri dari 3 taraf yaitu 1 gr/liter air, 2 gr/liter air dan 3 gr/liter air. Hasil Penelitian menunjukkan bahwa pupuk guano berpengaruh nyata terhadap jumlah helai daun dan panjang akar. Pemberian konsentrasi growmore berpengaruh nyata tehadap jumlah helai daun. Adanya interaksi nyata antara pupuk guano dan konsentrasi growmore terhadap diameter pangkal batang 90 HST.
\end{abstract}

Kata Kunci : Guano, growmore, kopi robusta

\section{Pendahuluan}

Kopi merupakan salah satu komoditas sektor perkebunan yang memegang andil besar baik dalam segi ekonomi maupun sosial. Komoditas kopi berada pada posisi keempat setelah kelapa sawit, karet dan kakao dalam penerimaan devisa Negara dari subsector perkebunan. Kopi terkenal akan kandungan kafein yang tinggi. Kafein sendiri merupakan senyawa hasil metabolism sekunder golongan alkanoid dari tanaman kopi dan memiliki rasa pahit (Arif, 2011). Hasil olahan kopi adalah salah satu minuman yang digemari masyarakat dunia sejak berabad-abad silam. Sampai saat ini kopi merupakan salah satu komoditas minuman yang paling akrab diberbagai lapisan (Cahyono dan Bambang, 2012).

Menurut data statistik dari International Coffee Organization pada tahun 2000-2010, konsumsi kopi dunia terus meningkat sebesar 3-4\% setiap tahunnya. Di Indonesia sendiri konsumsi masyarakat Indonesia akan kopi meningkat pesat sebesar $98 \%$ dalam 10 tahun terakhir. Pada tahun 2011 Indonesia menjadi produsen utama kopi ketiga setelah Vietnam dan Brasil dengan luas tanaman kopi diwilayah negara Indonesia yaitu 1.292.965 ha dengan hasil produksi sekitar 633.991 ton. Perkebunan kopi di Indonesia sekitar $96 \%$ merupakan usaha rakyat dengan skala yang masih kecil. Jenis tanaman kopi yang di budidaya oleh petani Indonesia yaitu kopi Arabika dan kopi Robusta. Masing-masing kopi memiliki keunggulan, kopi Arabika memiliki cita rasa yang khas sehingga mempunyai pasar khusus, sedangkan kopi Robusta (Defitri, 2016). Salah satu teknologi budi daya kopi meliputi pemilihan bibit kopi pemeliharaan, pemangkasan tanaman dan pemberian penaung, pengendalian hama dan gulma, pemupukan yang seimbang, pemanenan, serta pengolahan kopi pasca panen.

Pupuk guano adalah pupuk yang berasal dari kotoran kelelawar yang sudah 
mengendap lama di dalam gua dan telah bercampur dengan tanah dan bakteri pengurai. Pupuk guano mengandung nitrogen, fosfor dan potassium yang sangat bagus untuk mendukung pertumbuhan, merangsang akar, memperkuat batang bibit, serta mengandung unsure hara makro dan mikro yang di butuhkan bibit tanaman (Rasantika, 2009).

Pupuk Growmore memiliki kandungan unsur hara makro $\mathrm{N}(32 \%)$, P2O5 (10\%), K2O (10\%), Ca (0,05\%), Mg $(0,10 \%)$, dan $\mathrm{S}(0,20 \%)$, dan unsur-unsur hara mikro seperti $\mathrm{B}, \mathrm{Cu}, \mathrm{Fe}, \mathrm{Mn}, \mathrm{Mo}$, dan Zn. Pupuk growmore mudah larut dalam air mudah diserap tanaman, baik melalui penyemprotan daun maupun disiram ke dalam tanah dan dapat meningkatkan pertumbuhan tanaman pangan dan holtikulturan serta tanaman perkebunan (Lingga dan Marsono, 2013).

Penelitian ini bertujuan untuk mengetahui pengaruh pupuk guano dan pupuk growmore terhadap pertumbuhan bibit kopi robusta.

\section{Metodologi}

Penelitian dilaksanakan di Kebun Percobaan Fakultas Pertanian Universitas Jabal Ghafur Glee Gapui Sigli yang dimulai Juli sampai Oktober 2016.

Bahan yang akan di gunakan dalam penelitian ini adalah bibit kopi varietas Robusta, pupuk guano, Pupuk growmore, Polibag ukuran $20 \mathrm{~cm} \times 30 \mathrm{~cm}$ dan Tanah top soil.

Alat yang di gunakan dalam penelitian ini adalah cangkul, parang, meteran, jangka sorong, gunting, kamera, gembor, hand sprayer, papan plot, papan nama, alat tulis menulis dan alat-alat yang lain yang diperlukan dalam menunjang penelitian.

Penelitian ini menggunakan Rancangan Acak Kelompok (RAK) pola faktorial $4 \times 3$ dengan 3 ulangan. Faktor pertama pupuk guano terdiri dari 4 taraf yaitu 1 bagian pupuk guano dengan 2 bagian tanah (1:2), 1 bagian pupuk guano dengan 3 bagian tanah (1:3), 1 bagian pupuk guano dengan 4 bagian tanah (1:4) dan 1 bagian pupuk guano dengan 5 bagian tanah (1:5). Faktor kedua konsentrasi growmore terdiri dari 3 taraf yaitu $1 \mathrm{gr} /$ liter air, 2 gr/liter air dan 3 gr/liter air. Dengan demikian diperoleh 12 perlakuan dengan 3 ulangan sehingga secara keseluruhan terdapat 36 satuan percobaan.

Tabel 1. Susunan kombinasi perlakuan pupuk guano konsentrasi pupuk growmore

\begin{tabular}{|c|c|c|c|c|}
\hline $\mathrm{N}$ & Kombinas & Perba & $\operatorname{gan}$ & Konsentrasi \\
\hline o & $\begin{array}{c}\mathrm{i} \\
\text { Perlakuan }\end{array}$ & $\begin{array}{l}\text { Pupuk } \\
\text { Guano }\end{array}$ & $\begin{array}{c}\text { Tana } \\
\mathrm{h}\end{array}$ & $\begin{array}{c}\text { pupuk } \\
\text { growmore } \\
\text { (gr/ liter air) }\end{array}$ \\
\hline 1. & $\mathrm{G}_{1} \mathrm{M}_{1}$ & 1 & 2 & 1 \\
\hline 2. & $\mathrm{G}_{1} \mathrm{M}_{2}$ & 1 & 2 & 2 \\
\hline 3. & $\mathrm{G}_{1} \mathrm{M}_{3}$ & 1 & 2 & 3 \\
\hline 4. & $\mathrm{G}_{2} \mathrm{M}_{1}$ & 1 & 3 & 1 \\
\hline 5. & $\mathrm{G}_{2} \mathrm{M}_{2}$ & 1 & 3 & 2 \\
\hline 6. & $\mathrm{G}_{2} \mathrm{M}_{3}$ & 1 & 3 & 3 \\
\hline 7. & $\mathrm{G}_{3} \mathrm{M}_{1}$ & 1 & 4 & 1 \\
\hline 8. & $\mathrm{G}_{3} \mathrm{M}_{2}$ & 1 & 4 & 2 \\
\hline 9. & $\mathrm{G}_{3} \mathrm{M}_{3}$ & 1 & 4 & 3 \\
\hline 10 & $\mathrm{G}_{4} \mathrm{M}_{1}$ & 1 & 5 & 1 \\
\hline 11 & $\mathrm{G}_{4} \mathrm{M}_{2}$ & 1 & 5 & 2 \\
\hline 12 & $\mathrm{G}_{4} \mathrm{M}_{3}$ & 1 & 5 & 3 \\
\hline
\end{tabular}

\section{Persiapan Lahan}

Lahan dibersihkan dari rumput, semak, batu, ranting kayu dan kotoran lain dengan memperhatikan lahan yang datar yang ada di sekitar kebun.

\section{Pembuatan Naungan}

Pembuatan naungan dibuat dengan arah timur barat yang dimaksud agar cahaya matahari dapat masuk dari arah depan naungan. Adapun tinggi naungan adalah \pm 2 meter dibagian depan yang menghadap timur dan 1,75 meter dibagian belakang yang menghadap kebarat.

\section{Persiapan Media Tanam}

Tanah yang digunakan sebagai media tanam adalah tanah lapisan top soil yang diambil disekitar penelitian. Selanjutnya tanah diayak dengan ayakan pasir dengan 
tujuan untuk membersihkan tanah dari kotoran seperti batu dan plastik.

\section{Aplikasi Pupuk Guano}

Pupuk guano di berikan dengan cara mencampurkan dengan tanah sesuai dengan perbandingan perlakuan, selanjutnya dimasukan ke dalam polibag.

\section{Penyediaan Bibit}

Bibit yang digunakan adalah varietas Robusta, yang diperoleh dari Gampong Neubok Baduek Kecamatan Tangse Kabupaten Pidie. Bibit yang yang diambil yaitu bibit yang telah mempunyai 2 helai daun utama dengan kondisi tidak cacat dan mempunyai panjang yang sama.

\section{Penanaman}

Bibit yang diambil dari induk dipindahkan ke dalam plobag. Selanjutnya bibit tersebut disimpan selama 2 minggu dibawah naugan untuk proses seleksi. Bibi yang benar-benar sehat dan tingginya sama yang kemudian dipindahkan ke plot percobaan yang sudah disediakan. Penanaman dilakukan pada sore hari.

\section{Aplikasi Pupuk Growmore}

Pupuk growmore di berikan pada saat bibit berumur 20, 40, 60, 80 dan 100 hari setelah tanam (HST). Growmore diberikan dengan cara disemprot keseluruh bagian bagian tanaman. Penyemprotan di lakukan pada sore hari.

\section{Pemeliharaan}

Pemeliharaan meliputi : penyiraman, penyiangan dan dan pengendalian hama. Penyiraman dilakukan sebanyak 2 kali sehari yaitu pagi dan sore. Penyiangan dilakukan dengan cara mecabut gulma yang tumbuh di dalam polibag yang dilakuakn 2 minggu sekali.

\section{Pengamatan}

a. Tinggi bibit $(\mathrm{cm})$

Tingi bibit diukur mulai pangkal batang diatas permukaan tanah sampai ke ujung daun tertinggi pada umur 30, 50, 70, 90 dan 110 HST.

b. Diameter Pangkal Batang (mm)

Diameter pangkal batang diukur $5 \mathrm{~cm}$ dari permukaan tanah dengan menggunakan jangka sorong, pada umur 30, 50, 70, 90 dan 110 HST.

\section{c. Jumlah Daun (helai)}

Pengamatan jumlah daun dilakukan pada umur 30, 50, 70, 90, dan 110 HST.

d. Berat Brangkasan Basah (gr)

Berat brangkasan basah dilakukan pada akhir penelitian (110 HST) dengan cara bibit dibongkar, akar dibersihkan dari tanah yang melekat pada akar dan dicuci dengan air, kemudian brangkasan basah ditimbang.

e. Panjang Akar (cm)

Panjang akar dikur pada akhir penelitian dengan cara bibit dibongkar, akar dibersihkan dari tanah yang melekat dan dicuci dengan air kemudian akar diukur dalam satuan $\mathrm{cm}$.

\section{Hasil Dan Pembahasan \\ Pengaruh Pupuk Guano}

Tinggi Bibit $(\mathrm{cm})$

Hasil analisis ragam menunjukkan bahwa penggunaan jenis media tanam berpengaruh tidak nyata terhadap tinggi bibit kopi.

Tabel 2. Rata-rata tinggi bibit kopi robusta umur 30, 50, 70, 90 dan 110 HST akibat pupuk guano

\begin{tabular}{cccccc}
\hline Pupuk & \multicolumn{5}{c}{ Tinggi Bibit (cm) } \\
\cline { 2 - 6 } Guano & 30 & 50 & 70 & 90 & 110 \\
$(\mathrm{G})$ & HST & HST & HST & HST & HST \\
\hline $\mathrm{G}_{1}$ & 19,41 & 21,40 & 25,96 & 29,13 & 31,76 \\
$\mathrm{G}_{2}$ & 19,76 & 21,33 & 24,89 & 27,68 & 21,01 \\
$\mathrm{G}_{3}$ & 18,70 & 21,18 & 26,03 & 30,19 & 32,77 \\
$\mathrm{G}_{4}$ & 19,47 & 21,05 & 25,87 & 28,69 & 30,74 \\
\hline
\end{tabular}

Tabel 2 dapat dilihat bahwa tinggi bibit kopi robusta akibat pemberian pupuk guano tertinggi terdapat pada umur $30 \mathrm{HST}$ pada perlakuan G2, umur 50 HST pada perlakuan G1, sedangkan umur 70, 90 dan 110 pada perlakuan G3. Meskipun secara statistik tidak berpengaruh tetapi adanya peningkatan tinggi bibit kopi robusta akibat pemberian guano pada umur 110 HST. Dimana semakin lama umur bibit maka semakin tinggi bibit kopi robusta. 
Pupuk guano mengandung senyawa organik diantaranya nitrogen, fosfor, dan potassium yang sangat bagus untuk mendukung pertumbuhan tanaman (Samijan, 2010).

\section{Diameter Pangkal Batang (cm)}

Hasil analisis ragam menunjukkan bahwa penggunaan pupuk guano berpengaruh tidak nyata terhadap diameter pangkal batang bibit kopi robusta umur 30, 50, 70, 90 dan 110 HST.

Tabel 3. Rata-rata diameter pangkal batang bibit kopi robusta umur 30, 50, 70, 90 dan 110 HST akibat pupuk guano

\begin{tabular}{cccccc}
\hline Pupuk & \multicolumn{5}{c}{ Diameter pangkan batang $(\mathrm{cm})$} \\
\cline { 2 - 6 } Guano & 30 & 50 & 70 & 90 & 110 \\
$(\mathrm{G})$ & $\mathrm{HST}$ & HST & HST & HST & HST \\
\hline $\mathrm{G}_{1}$ & 0,93 & 0,98 & 1,03 & 1,16 & 1,30 \\
$\mathrm{G}_{2}$ & 0,96 & 0,99 & 1,03 & 1,14 & 1,40 \\
$\mathrm{G}_{3}$ & 0,92 & 0,98 & 1,02 & 1,19 & 1,34 \\
$\mathrm{G}_{4}$ & 0,92 & 0,95 & 1,03 & 1,16 & 1,29 \\
\hline
\end{tabular}

Tabel 3 menunjukkan bahwa diameter pangkal batang yang tertinggi dijumpai pada G2 dan G3. Sedangkan yang terendah terdapat pada perlakuan G4, G3 dan G2. Meskipun secara statistik tidak berpengaruh tetapi adanya peningkatan diameter pangkal batang bibit kopi robusta akibat pemberian guano pada umur 110 HST. Dimana semakin lama umur bibit maka semakin tinggi bibit kopi robusta. Hal ini diduga pemberian pupuk guano belum mampu meningkatkan basa-basa tanah seperti unsure $\mathrm{Ca}, \mathrm{Mg}$, dan $\mathrm{K}$ secara nyata. Sejalan dengan Gardner et al., (1993) yang mengemukakan bahwa apabila ketersediaan unsure hara cukup dan seimbang selama pertumbuhan tanaman maka akan berperan dalam pembentukan batang, pelebaran daun sehingga pada akhirnya akan meningkatkan produksi tanaman.

\section{Jumlah Daun (helai)}

Hasil analisis ragam menunjukkan bahwa pemberian pupuk guano berpengaruh nyata terhadap jumlah daun pada umur 90 HST, namun tidak berpengaruh nyata pada umur 30, 50, 70 dan 110 HST.
Tabel 4. Rata-rata jumlah daun bibit kopi robusta umur 30, 50, 70, 90 dan 110 HST akibat pupuk guano

\begin{tabular}{cccccc}
\hline Pupuk & \multicolumn{5}{c}{ Jumlah Daun (helai) } \\
\cline { 2 - 6 } $\begin{array}{c}\text { Guano } \\
(\mathrm{G})\end{array}$ & 30 & 50 & 70 & 90 & 110 \\
& $\mathrm{HS}$ & $\mathrm{HST}$ & HST & HST & HST \\
\hline $\mathrm{G}_{1}$ & 4,74 & 5,56 & 7,56 & $8,96 \mathrm{~b}$ & 9,41 \\
$\mathrm{G}_{2}$ & 5,33 & 5,93 & 7,70 & $8,37 \mathrm{a}$ & 9,41 \\
$\mathrm{G}_{3}$ & 4,96 & 5,56 & 7,41 & $9,04 \mathrm{~b}$ & 9,48 \\
$\mathrm{G}_{4}$ & 4,44 & 5,56 & 7,67 & $8,89 \mathrm{ab}$ & 9,41 \\
BNJ 0,05 & & & & 0,55 & \\
\hline
\end{tabular}

Ket: Angka yang diikuti oleh huruf yang sama pada kolom yang sama tidak berbeda nyata pada taraf $a=5 \%$ (Uji BNJ)

Tabel 4 dapat menunjukkan jumlah daun bibit kopi robusta terbanyak dijumpai pada umur 90 HST pada perlakuan G3 tidak berbeda dengan perlakuan G1 dan G4 kecuali G2. Sedangkan jumlah daun terendah dijumpai pada perlakuan G2, tetapi tidak berbeda dengan perlakuan G4.

Jumlah daun berbanding lurus dengan tinggi tanaman dimana semakin tinggi tanaman maka jumlah daunnya akan semakin banyak. Salah satu yang menyebabkan bertambahnya jumlah daun pada tanaman adalah adanya suplai hara ke dalam tanaman secara optimal (Fahriani, 2007).

\section{Berat Brangkasan Basah (gr)}

Hasil analisis ragam menunjukkan bahwa pemberian pupuk guano berpengaruh tidak nyata terhadap berat brangkasan basah bibit kopi robusta.

Tabel 5. Rata-rata berat brangkasan basah bibit kopi robusta akibat pupuk guano

\begin{tabular}{cc}
\hline Pupuk Guano $(\mathrm{G})$ & Berat Brangkasan Basah $(\mathrm{gr})$ \\
\hline $\mathrm{G} 1$ & 20,37 \\
$\mathrm{G}_{2}$ & 18,15 \\
$\mathrm{G}_{3}$ & 20,93 \\
$\mathrm{G}_{4}$ & 14,10 \\
\hline
\end{tabular}

Tabel 5 menunjukkan berat brangkasan basah bibit kopi robusta terbanyak akibat perlakuan pupuk guano dijumpai pada perlakuan G3 (20,37 gr), sedangkan terendah dijumpai pada perlakuan G4 (14,10 gr). Kelembaban tanah 
yang baik akan meningkatkan metabolism tanaman yang diikuti dengan meningkatnya pertumbuhan tanaman. Hal ini disebabkan karena proses penyerapan zat hara dapat berlangsung baik. Pada kelembaban tanah yang baik akar akan lebih mudah menyerab zat nitrogen dan fosfat. Kelembaban udara dan kelembaban tanah yang sesuai akan memberikan pertumbuhan tanaman yang baik dan produksi yang tinggi (Cahyono, 2003).

\section{Panjang Akar (cm)}

Hasil analisis ragam menunjukkan bahwa pemberian pupuk guano berpengaruh nyata terhadap panjang akar bibit kopi robusta.

Tabel 6. Rata-rata panjang akar bibit kopi robusta akibat pupuk guano.

\begin{tabular}{cc}
\hline Pupuk Guano (G) & Panjang Akar (cm) \\
\hline G1 & $27,19 \mathrm{~b}$ \\
$\mathrm{G}_{2}$ & $20,19 \mathrm{ab}$ \\
$\mathrm{G}_{3}$ & $25,26 \mathrm{ab}$ \\
$\mathrm{G}_{4}$ & $17,52 \mathrm{a}$ \\
\hline BNJ 0,05 & 8,50 \\
\hline
\end{tabular}

Ket : Angka yang diikuti oleh huruf yang sama tidak berbeda nyata pada taraf $a=5$ $\%$ (Uji BNJ)

Tabel 6 dapat dijelaskan bahwa ratarata panjang akar bibit kopi robusta tertinggi dijumpai pada perlakuan G1 $(27,19)$ tidak berbeda dengan perlakuan G2 $(20,19)$ dan G3 $(25,26)$. Sedangkan panjang akar bibit kopi robusta terendah dijumpai pada perlakuan G4 $(17,52)$ tidak berbeda dengan perlakuan G1 dan G2. Perlakuan G1 $(27,19)$ sangat berbeda dengan perlakuan G4 $(17,52)$. Pupuk guano perbandingan 1 bagian guano dengan 5 bagian tanah berbeda nyata dengan perlakuan 1 bagian guano dengan 2 bagian tanah terhadap panjang akar.

Tanaman dalam menyerap unsure hara dalam tanah sangat dipengaruhi oleh factor lingkungan, salah satunya keadaan air tanah.
Air bagi tanaman berfungsi sebagai pelarut hara, berperan dalam translokasi hara dan fotosintesis. Adanya air yang yang cukup berarti lebih banyak tersedia unsure hara dalam larutan tanah. Salah satu unsure terserap tanaman adalah nitrogen. Nitrogen diserap tanaman dalam bentuk ion nitrat dan ammonium (Evita, 2012).

\section{Pengaruh Konsentrasi Growmore Tinggi Bibit}

Hasil analisis ragam menunjukkan bahwa perlakuan konsentrasi growmore berpengaruh tidak nyata terhadap tinggi bibit kopi robusta.

Tabel 7. Rata-rata tinggi bibit kopi robusta umur 30, 50, 70, 90 dan 110 HST akibat konsentrasi growmore

\begin{tabular}{|c|c|c|c|c|c|}
\hline \multirow{2}{*}{$\begin{array}{c}\text { Pupuk } \\
\text { Growmore } \\
\text { (gr/L) }\end{array}$} & \multicolumn{5}{|c|}{ Tinggi Bibit $(\mathrm{cm})$} \\
\hline & $\begin{array}{c}30 \\
\text { HST }\end{array}$ & $\begin{array}{c}50 \\
\text { HST }\end{array}$ & $\begin{array}{c}70 \\
\text { HST }\end{array}$ & $\begin{array}{c}90 \\
\text { HST }\end{array}$ & $\begin{array}{c}110 \\
\text { HST }\end{array}$ \\
\hline $\mathrm{M}_{1}$ & 19,31 & 21,13 & 25,54 & 29,36 & 31,87 \\
\hline $\mathrm{M}_{2}$ & 19,48 & 21,04 & 25,34 & 27,86 & 30,61 \\
\hline $\mathrm{M}_{3}$ & 19,22 & 21,55 & 26,18 & 29,53 & 32,23 \\
\hline
\end{tabular}

Berdasarkan Tabel 7 dapat dilihat bahwa semakin lama umur bibit maka akan semakin tinggi bibit, meskipun menurut uji statistik tidak berpengaruh. Tinggi bibit tetinggi dijumpai umur bibit $30 \mathrm{HST}$, dan terendah juga dijumpai pada umur bibit 30 HST. Umur bibit akan meningkat seiring meningkatnya umur bibit yaitu umur 50, 70, 90 dan 110 HST. Variasi respon terhadap pemberian zat pengatur tumbuh dipengaruhi oleh perbedaan fase pertumbuhan, kondisi fisik, kemampuan tanaman mengadopsi zat pengatur tumbuh, serta fluktuasi kandungan hormone endogen pada beberapa kondisi fisiologi (Surtinah, 2013).

Diameter Pangkal Batang $(\mathrm{cm})$

Hasil analisis ragam menunjukkan bahwa penggunaan pupuk guano berpengaruh tidak nyata terhadap diameter pangkal batang bibit kopi robusta umur 30, 50, 70, 90 dan 110 HST. 
Tabel 8. Rata-rata diameter pangkal batang bibit kopi robusta umur 30, 50, 70, 90 dan 110 HST akibat konsentrasi growmore

\begin{tabular}{cccccc}
\hline Pupuk & \multicolumn{5}{c}{ Diameter } \\
\cline { 2 - 6 } Growmongkal batang $(\mathrm{cm})$ \\
\cline { 2 - 6 }$(\mathrm{gr} / \mathrm{L})$ & 30 & 50 & 70 & 90 & 110 \\
\hline $\mathrm{M}_{1}$ & 0,93 & 0,98 & 1,03 & 1,16 & 1,39 \\
$\mathrm{M}_{2}$ & 0,92 & 0,96 & 1,02 & 1,13 & 1,28 \\
$\mathrm{M}_{3}$ & 0,94 & 0,99 & 1,03 & 1,20 & 1,33 \\
\hline
\end{tabular}

Berdasarkan Tabel 8 menunjukkan bahwa diameter pangkal batang terbanyak pada umur 30, 50, 70 dan 90 HST terdapat pada perlakuan M3, sedangkan umur 110 HST dijumpai pada perlakuan M1. Diameter pangkal batang terendah terdapat pada perlakuan M2. Lewenussa (2009) menyatakan bahwa pada usia muda tanaman cendrung melakukan pertumbuhan yang cepat kea rah vertical (keatas). Pertumbuhan kearah diameter bibit berlangsung apabila keperluan hasil fotosintesis untuk respirasi, pergantian daun, pergantian akar dan tinggi telah terpenuhi. Pertumbuhan panjang tunas dipengaruhi oleh hormon auksin dan sitokinin. Sitokinin akan merangsang pembelahan sel melalui peningkatan laju sintesis protein, sedangkan auksin akan memacu pemanjangan sel-sel sehingga menyebabkan pemanjangan batang (Lakitan, 2011).

\section{Jumlah Daun (helai)}

Hasil analisis ragam menunjukkan bahwa pemberian pupuk growmore berpengaruh nyata terhadap jumlah daun pada umur 110 HST dan berpengaruh tidak nyata pada umur 30, 50, 70 dan 90 HST.

Tabel 9. Rata-rata jumlah daun bibit kopi robusta umur 30, 50, 70, 90 dan 110 HST akibat pupuk growmore

\begin{tabular}{cccccc}
\hline Pupuk & \multicolumn{5}{c}{ Jumlah Daun (helai) } \\
\cline { 2 - 6 } Growmor & 30 & 50 & 70 & 90 & 110 \\
$\mathrm{e}(\mathrm{gr} / \mathrm{L})$ & HST & HST & HST & HST & HST \\
\hline $\mathrm{M}_{1}$ & & 5,61 & 7,61 & & $9,44 \mathrm{a}$ \\
& 4,89 & & & 8,94 & $\mathrm{~b}$ \\
$\mathrm{M}_{2}$ & 4,78 & 5,78 & 7,58 & 8,61 & $9,00 \mathrm{a}$ \\
$\mathrm{M}_{3}$ & & 5,56 & 7,56 & & 9,83 \\
& 4,94 & & & 8,89 & $\mathrm{~b}$ \\
\hline BNJ 0,05 & & & & & 0,76 \\
\hline
\end{tabular}

Ket: Angka yang diikuti oleh huruf yang sama tidak berbeda nyata pada taraf $a=5$ $\%$ (Uji BNJ)

Tabel 9 dapat dijelaskan bahwa ratarata jumlah daun bibit kopi robusta terbanyak akibat pemberian pupuk growmore terdapat pada perlakuan M3 $(9,83)$ yang berbeda nyata dengan perlakuan M2, namun tidak berbeda dengan perlakuan M1. Sedangkan jumlah daun terendah terdapat pada perlakuan M2 $(9,00)$ tidak berbeda dengan perlakuan M2 (2 gr/L air).

Jumlah daun yang muncul berhubungan dengan tinggi tanaman dimana penambahan tinggi tanaman menyebabkan daun yang terbentuk juga banyak. Terjadinya jumlah daun suatu tanaman disebabkan oleh peristiwa pembelahan dan perpanjang sel yang didominasi dibagian ujung pucuk. Pupuk growmore mengandung unsur NPK, dimana kalium merupakan unsure hara yang berperan sebagai aktivator dari berbagai enzim yang esensial dalam reaksi fotosintesis. Selain NPK ada juga unsure yang terdapat dalam pupuk growmore yaitu Mg (Husma, 2010).

\section{Berat Brangkasan Basah (gr)}

Hasil analisis ragam menunjukkan bahwa konsentrasi pupuk growmore berpengaruh tidak nyata terhadap berat brangkasan basah bibit kopi robusta.

Tabel 10. Rata-rata berat brangkasan basah bibit kopi robusta akibat pupuk growmore

\begin{tabular}{cc}
\hline $\begin{array}{c}\text { Pupuk Growmore } \\
(\mathrm{gr} / \mathrm{L})\end{array}$ & Berat Brangkasan Basah $(\mathrm{gr})$ \\
\hline $\mathrm{M}_{1}$ & 19,19 \\
$\mathrm{M}_{2}$ & 16,39 \\
$\mathrm{M}_{3}$ & 19,58 \\
\hline
\end{tabular}

Berdasarkan Tabel 10 dapat dilihat bahwa berat brangkasan basah tertinggi akibat pupuk growmore terdapat pada perlakuan M3 $(19,58)$, sedangkan terendah terdapat pada perlakuan M2 $(16,39)$. Hal ini dikarenakan unsure-unsur hara yang terdapat dalam pupuk belum dapat dimanfaatkan oleh tanaman secara optimal. Berat brangkasan tanaman mencerminkan 
akumulasi senyawa organik yang berhasil disintesis tanaman dari senyawa anorganik (unsur hara, air, dan karbohidrat),semakin tinggi berat brangkasan basah tanaman berarti semakin baik pertumbuhan bibit (Putri dan Nurhasybi, 2010).

\section{Panjang Akar (cm)}

Hasil analisis ragam menunjukkan bahwa pupuk growmore berpengaruh tidak nyata terhadap panjang akar bibit kopi robusta.

Tabel 11. Rata-rata panjang akar bibit kopi robusta akibat pupuk growmore

\begin{tabular}{cc}
\hline $\begin{array}{c}\text { Pupuk Growmore } \\
(\mathrm{gr} / \mathrm{L})\end{array}$ & Panjang Akar (cm) \\
\hline $\mathrm{M}_{1}$ & 24,06 \\
$\mathrm{M}_{2}$ & 21,03 \\
$\mathrm{M}_{3}$ & 22,53 \\
\hline
\end{tabular}

Tabel 11 dapat dijelaskan bahwa ratarata panjang akar bibit kopi robusta terbanyak akibat pupuk growmore dijumpai pada perlakuan M1 (1 gr/L air), sedangkan terendah terdapat pada perlakuan M2 (2 gr/L air). Dwi (2006) mengemukakan bahwa didalam tubuh tanaman unsure hara $\mathrm{Ca}$ mempunyai fungsi utama dalam pertumbuhan terutama memproduksi dinding sel, mempercepat pertumbuhan akar dan mempermudah penyerapan $\mathrm{K}$, sedangkan $\mathrm{Mg}$ berperan dalam pendistribusian fosfor ke seluruh bagian tanaman.

\section{Kesimpulan}

1. Pemberian pupuk guano berpengaruh nyata terhadap jumlah daun 90 HST dan panjang akar. Pupuk guano terbaik terdapat pada G1 (1 bagian tanah dengan 2 bagian tanah)

2. Pemberian konsentrasi pupuk growmore berpengaruh sangat terhadap jumlah daun umur 110 HST. Konsentrasi pupuk growmore terbaik dijumpai pada perlakuan 3gr/ liter air (M3).

3. Tidak terdapat interaksi yang nyata terhadap tinggi bibit, diameter pangkal batang, jumlah daun, berat brangkasan basah dan panjang akar.

\section{Daftar Pustaka}

Arif, M. W. (2011), Budidaya Kopi Konservasi,C.I Indonesia.

Cahyono dan Bambang. 2012. Sukses Berkebun Kopi. Penerbit Mina. Jakarta.

Cahyono, B. 2003. Teknik dan Strategi Budidaya Sawi Hijau. Yogyakarta. Gavamedia.

Defitri. Y. 2016. Pengamatan Beberapa Penyakit Yang Menyerang Tanaman Kopi (Coffea Sp) Di Desa Mekar Jaya Kecamatan Betara Kabupaten Tanjung Jabung Barat. Jurnal Media Pertanian.

Dwi, C.O.,Rejeki, A dan Teguh, S. 2006. Pengaruh Dosis Pupuk Organik Cair dan Macam Tanah Terhadap Pertumbuhan Awal Mahkota Dewa (Phalleria macrocorpa). Universitas Tunas Pembangunan. Surakarta.hal 10.

Evita. 2012. Pertumbuhan dan Hasil Kacang Tanah (Arachis hypogea L.) pada Perbedaan Tingkatan Kandungan Air. Buletin Agronomi Universitas Jambi. I (I):26-32.

Fahriani, Y.,2007. Pengaruh Pemberian Vermikompos Sampah Daun Terhadap Beberapa Sifat Fisika Tanah dan Pertumbuhan Tanaman Jagung (Zea mays L) pada Alfisol Jatikerto. Fakultas Peranian. Universitas Brawijaya.

Gardner, P.F.,R.B. Pearce and R.I. Mitchell. 1993. Physiology og Crop Plants. The Lowa State University Press. Jakarta. 
Husma, M.2010. Pengaruh Bahan Organik dan Pupuk Kalium Terhadap Pertumbuhan dan Produksi Tanaman Melon (Cucumis melo L). Pascasarjana Unhalu. Kendari.

Lakitan, B. 2011. Dasar-Dasar Fisiologi Tumbuhan. Raja Grafindo Persada. Jakarta.

Lewenussa, A. 2009. Pengaruh Mikoriza dan Bioorganik terhadap Pertumbuhan Bibit Cananga Odorata. Skripsi. Fakultas Kehutanan, IPB. Bogor.

Lingga, P. \& Marsono. 2013. Petunjuk Penggunaan Pupuk. Penebar Swadaya. Perum Bukit Permai. Cibubur. Jakarta Timur.

Putri. K. P dan Nurhasybi. 2010. Pengaruh Jenis Media Organik terhadap Kualitas Bibit Takir. Jurnal. Penelitian Hutan Tanaman.

Rasantika, M.S. 2009. Guano Kotoran Burung yang Menyuburkan. Gramedia. Jakarta

Samijan, 2010. Pupuk Guano. Pusat Penelitian Pengembangan Pertanian. Bogor.

Sutirnah, E. 2013. Frekuensi Pemberian Grow Quick L.b Terhadap Pertumbuhan Bibit Anggrek Dendrobium pada Stand Komunitas Pot. Jurnal Pertanian. 10 (2):31-40. 